\title{
Heavy metals accumulation in vegetables grown along the Msimbazi River in Dar es Salaam, Tanzania
}

\author{
Charles KIHAMPA * and William J.S. MWEGOHA \\ Department of Environmental Science and Management, Ardhi University, P.O. Box 35176, Dar es Salaam, \\ Tanzania. \\ *Corresponding Author; Email: kihampa@yahoo.com ; Tel. +255-22-2771272; Fax (255) 222775391
}

\begin{abstract}
Concentrations of cadmium, copper, chromium and lead was determined in four different edible vegetables namely Amaranthus blitum, A. gangeticus, Ipomea batata and Cucurbita maxima grown at four different sites along the contaminated Msimbazi River, Dar es Salaam, Tanzania. Analyses of these heavy metals were conducted using Atomic Absorption Spectrophotometry. Results obtained indicate that the concentrations of heavy metals range from below detection limit to $0.53,0.14$ to $29.08,0.76$ to 17.69 , and below detection limit to $39.69 \mathrm{mg} / 100 \mathrm{~g}$ for cadmium, chromium, copper and lead, respectively. With exception to Ipomea batata, other vegetables contained at least two types of heavy metals with high concentrations beyond the permissible values recommended by FAO and WHO for human consumption. Concentrations of cadmium were within the acceptable limits for human consumption in all the vegetables investigated. This work, thus, seeks to provide information on levels of toxic heavy metals in leaves of edible vegetables irrigated with water contaminated by industrial and other anthropogenic effluents, and grown in contaminated soils along the Msimbazi River. The information can be used for monitoring processes to prevent excessive build-up in the food chain.
\end{abstract}

(C) 2010 International Formulae Group. All rights reserved.

Keywords: Heavy metals, Vegetables, Msimbazi River, Dar es Salaam.

\section{INTRODUCTION}

Vegetables constitute essential components of the diet by contributing proteins, vitamins, iron, calcium and other nutrients which are usually in short supply. They also act as buffering agents for acidic substances obtained during the digestion process (Shamar et al., 2009). Whilst support for increased production and consumption of fresh vegetables is an important goal, growing vegetables have become one of the major concerns for urban agriculture due to heavy metals and other toxic chemicals contamination and bioaccumulation in vegetable.

Ingestion of contaminated food is one of the main routes through which heavy metals enter the human body (Grasmück and Scholz, 2005). Trace quantities of certain metals such as chromium, cobalt, copper, manganese and zinc are essential micronutrients for higher animals and plant growth. Other metals such as cadmium, arsenic, mercury, lead, chromium and nickel 
are contaminants and are associated with developmental abnormalities in children, blood neutrophils, acute and chronic poisoning (D’Mello, 2003; Mushtakova et al., 2005).

With the rapid development of manufacturing industries, agriculture, traffic and transportation, and mining, heavy metals contamination is increasingly becoming a serious problem in some regions, particularly in developing countries (Muchuweti et al., 2006). In Tanzania, Dar es Salaam in particular, it has been a common practice to cultivate vegetables along the banks of the rivers passing through the city. Waters of these rivers are reported to be polluted by heavy metals, which include $\mathrm{Pb}, \mathrm{Cu}, \mathrm{Zn}, \mathrm{Fe}$, Cr, Cd and Hg (Mashauri and Mayo, 1990). The major sources of these heavy metals are industrial effluents, and indiscriminate disposal of domestic or sewage drainage directed to the rivers untreated or partially treated. Msimbazi River, for instance, which flows through the Dar es Salaam industrial area, by 1988 had an average sewage and industrial effluents rate of $256 \mathrm{~m}^{3} / \mathrm{h}$ with peak values of $606 \mathrm{~m}^{3} / \mathrm{h}$, just before it enters the Indian Ocean (Ak'habuhaya and Lodenius, 1989). Because of economic considerations, people of middle and low income groups in Dar es Salaam, consume significant quantities of vegetables such as African spinach (Amaranthus blitum, A. gangeticus), Sweet potatoes (Ipomea batata) and Pumpkin (Cucurbita maxima). The aim of this research was to investigate the levels of heavy metals in selected edible vegetables irrigated with contaminated water and grown in contaminated soils along the sites of Msimbazi River, Dar es Salaam.

\section{MATERIALS AND METHODS Description of the study area}

The study was conducted along the Msimbazi River, which is located within the city of Dar es Salaam. The river originates from the highlands of Kisarawe in Coastal region and covers a distance of about $45 \mathrm{~km}$. It flows towards the north east and enters the
Indian Ocean on the northern part of the City (Fig. 1). On its way it is joined by other tributaries and open channels most being conduit of effluents from different parts of the City. The tributaries include Mambizi, Luhanga, Sinza, Ubungo, Zimbile, Kinyenyele and Kwangula streams. The effluents include discharges from manufacturing industries such as batteries, steel, paints and dyes, electrical products and food processing industries located along the Nyerere road, Magomeni, Ilala, Kariakoo, Muhimbili hospital and Vingunguti abattoir. The river is of meandering nature, widening at one location and narrowing at other locations due to varied stability of the river banks. Different activities are carried along the river banks, among them are vegetable cultivation and irrigation, fishing, sand mining for housing construction, bricks making etc. The investigated sites along the rivers are well known for vegetable growing which is practiced through out the year. The production of the vegetable starting from irrigation, washing of the harvested vegetable, cleansing of field equipments and other general use within these areas are enabled by the use of the contaminated water from the river.

\section{Sample collection}

Four sampling locations were established along the Msimbazi River. These fields include (Fig. 1 and Table 1) Jangwani behind Kajima industrial area where Msimbazi joins with Luhanga stream (SI), Kigogo commonly known as Msimbazi Valley or SUKITA (S2), Tabata Shule (S3) and Vingunguti (S4). Four types of vegetables namely Amaranthus blitum, A. gangeticus, Ipomea batata and Cucurbita maxima were collected from four locations along the cultivated banks of the river Msimbazi. Sixteen (16) samples of leaves per vegetable were collected, making a total of 64 vegetable samples. The samples were collected over a period of six months during the dry season (July-December) of the year 2009. All samples were collected and stored in polythene bags according to their type and brought to the laboratory for preparation and analysis. The vegetable materials were 
authenticated at the Herbarium of the Department of Botany at the University of Dar es Salaam, Tanzania where voucher specimens are preserved.

\section{Sample preparation and treatment}

The samples were washed with distilled water to eliminate air-borne pollutants. The leafy stalks were removed from all samples and these were sliced and oven dried to eliminate excess moisture. The samples were weighed and oven-dried at $60{ }^{\circ} \mathrm{C}$ to constant weight. Each oven-dried sample was ground in porcelain mortar to a fine powder that passed through a $0.18 \mathrm{~mm}$ sieve. The samples were then stored in a clean, dry, stopper glass container before analysis.

\section{Determination of heavy metals Reagents}

All standard reagents used were of analytical grade obtained from Romil limited, England.

\section{Extraction of the vegetable samples}

Nitric acid-perchloric acid digestion method was used (Clesceri et al., 1998). Each determination was carried out by measuring a sample of $1 \mathrm{~g}$ of a ground sample in a crucible. The ground sample was transferred into a beaker, digested with $5 \mathrm{ml}$ of nitric and evaporated at $90{ }^{\circ} \mathrm{C}$ for at least one hour to moist salts. The digestion process was repeated until no visible charred materials were present. The samples were allowed to cool followed by addition of $5 \mathrm{ml}$ of perchloric acid, then heated slowly until the solution cleared and evaporated to moist salts. The residue was dissolved in $2 \mathrm{ml}$ of nitric acid, filtered into a $50 \mathrm{ml}$ volumetric flask using Whatman filter paper No. 41, and the solution was made to the mark with deionised water. Atomic absorption spectrophotometry (AAS) was used for the determination of the heavy metals. Each sample solution was run in duplicate to ensure the reproducibility of the obtained results. The same procedure was followed for each sample and the appropriate dilution factors were used in the calculation.

\section{The atomic absorption spectrophotometry (AAS) determination}

The extracted solution was aspirated into the instrument after all necessary set-up and standardization procedures. Heavy metals were determined using Perkin Elmer Analyst 100 AAS with Perkin Elmer HGA 850 Graphite Furnace and Perkin Elmer AS 800 Auto-sampler made in Germany. For analytical quality assurance, after every five sample readings, standards were run to make sure that the margin of error is within $5 \%$. A $10 \mathrm{~cm}$ long slot-burner head, a lamp and a standard air-acetylene flame were used. The detection limit was $0.01 \mathrm{ppm}(0.001 \mathrm{mg} / 100$ g), slit width $0.70 \mathrm{~nm}$ and elements wavelength were 228.8, 357.9, 324.8 and $283.3 \mathrm{~nm}$ for $\mathrm{Cd}, \mathrm{Cr}, \mathrm{Cu}$ and $\mathrm{Pb}$, respectively. Analytical quality

Quality control measures in analytical procedure were taken to confirm the accuracy of the analytical data. Two reference plant materials were digested in a similar manner to the vegetable samples for quality control and to monitor any instrument variability. The reference vegetables were grown in the experimental hut at Ardhi University. In every analytical batch, $10 \%$ samples of all were analyzed repeatedly to ensure the precision and accuracy of analysis. Standard reagents and blanks were also used in the process of analysis to ensure the precision.

\section{Estimation of daily intake of heavy metals through vegetables}

The daily intake of heavy metals through the consumption of the vegetables tested was calculated according to the equation given below (Cui et al., 2004):

Daily intake of heavy metals $(\mu \mathrm{g} /$ day $)=$ (Daily vegetable consumption $\mathbf{x}$ average vegetable heavy metal concentration).

Daily vegetable consumption was obtained through a formal survey conducted in the study area. An interview of 50 persons of (35 vegetable growers and 15 vendors) 3050 years age group and average of $60-70 \mathrm{~kg}$ body weight was conducted at each market site regarding their daily consumption rate of vegetables tested. 


\section{Statistical analysis}

Mean concentrations of heavy metals in vegetables were calculated using a statistical package INSTANT ${ }^{\circledR}$. Multiple comparison with one way ANOVA were used to test the significant differences of heavy metal concentrations within one plant species and across various plant species $(\alpha=0.05)$.

\section{RESULTS}

\section{Heavy metals concentrations in vegetables}

The mean concentrations of $\mathrm{Cd}, \mathrm{Cr}, \mathrm{Cu}$ and $\mathrm{Pb}$ in leaves of A. blitum, A. gangeticus, I. batata and C. maxima are given in Table 2 . The values $(\mathrm{mg} / 100 \mathrm{~g} \mathrm{dw})$ ranged from 0.13 to $29.17,0.76$ to 15.87 , bdl to 39.69 and bdl to 0.53 for $\mathrm{Cr}, \mathrm{Cu}, \mathrm{Pb}$ and $\mathrm{Cd}$, respectively. The trend of heavy metals accumulation in vegetables were in the order of A. blitum $>A$. gangeticus $>$ C. maxima $>$ I. batata, with $\mathrm{Pb}$ and $\mathrm{Cd}$ be the highest and lowest, respectively $(\mathrm{Pb}>\mathrm{Cr}>\mathrm{Cu}>\mathrm{Cd})$. Among the vegetables, mean concentrations of $\mathrm{Pb}$ and $\mathrm{Cu}$ were highest in $A$. gangeticus but mean concentration of $\mathrm{Cr}$ was highest in A. blitum.

\section{Estimation of exposure to heavy metals through ingestion}

Daily average consumption of vegetable per person per day was $105 \mathrm{~g} \mathrm{dw}$, as obtained from a survey conducted in the study area. The amount is approximately the same as that reported in the Coastal region of Tanzania which is $108 \mathrm{~g}$ of the average food ration of $1587 \mathrm{~g}$ (Lukwanjo and Tanner, 1985). Estimated daily heavy metals intake per person per day through consumption of vegetable was found high in A. gangeticus followed by A. blitum and then C. maxima (Table 2).

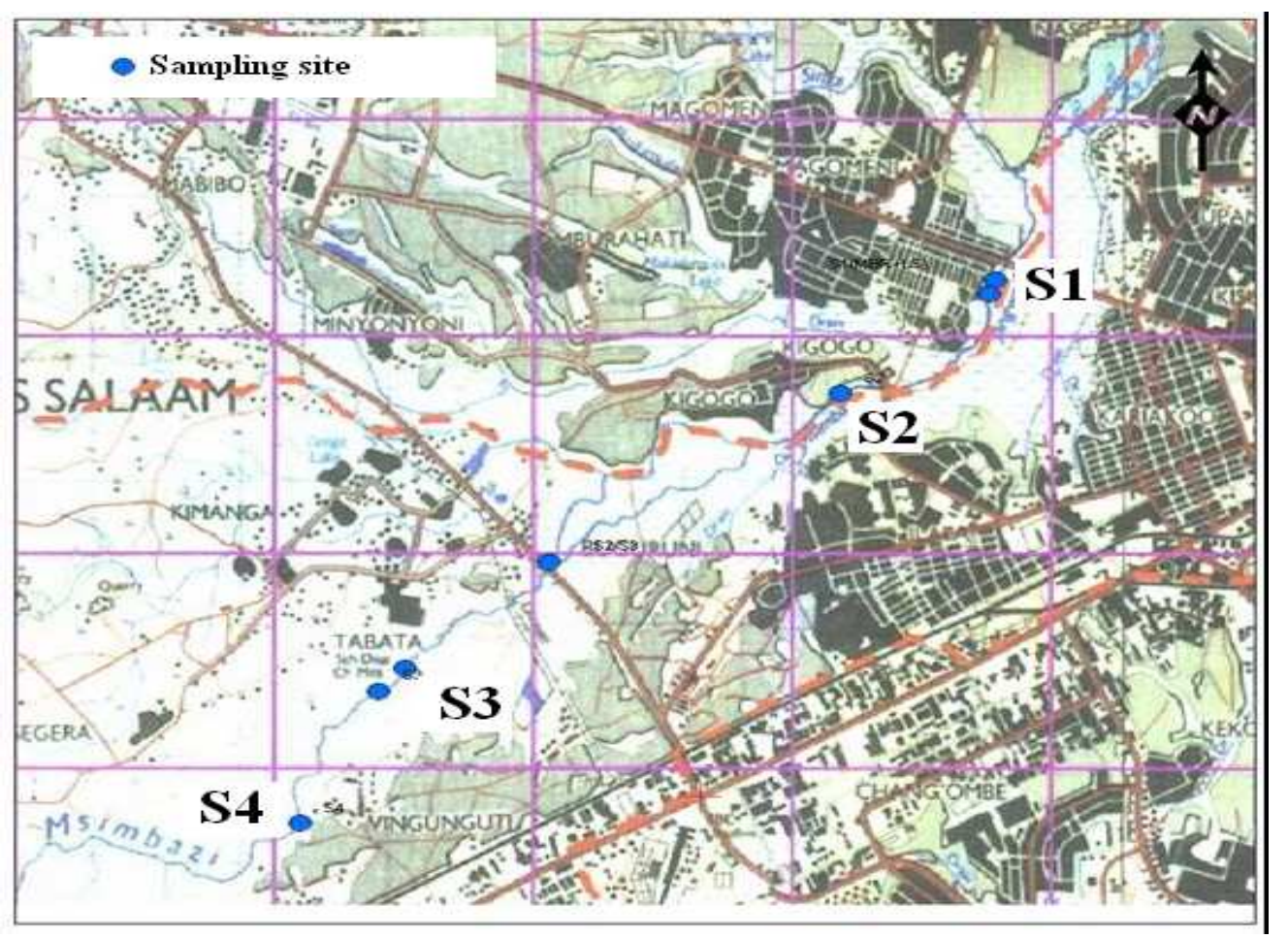

Figure 1: Location of Msimbazi River and sampling sites. 
Table 1: Sampling points along the Msimbazi River.

\begin{tabular}{llll}
\hline Sampling point & Eastings & Northings & Description \\
\hline S1 (Jangwani) & 527181 & 9244180 & Msimbazi River joins with Luhanga Stream \\
S2 (Kigogo) & 527103 & 9244109 & Msimbazi valley \\
S3(Tabata Shule) & 526861 & 9243898 & Receives wastes from different industries \\
S4 (Vingunguti) & 526820 & 9243804 & Vingunguti WSPs joins Msimbazi River \\
\hline
\end{tabular}

Table 2: Heavy metal concentrations in vegetables and estimated heavy metals daily dietary intake per person.

\begin{tabular}{|c|c|c|c|c|c|}
\hline \multirow[t]{2}{*}{ Sampling location } & \multirow[t]{2}{*}{ Vegetable } & \multicolumn{4}{|c|}{ Heavy metal mean concentration $\pm \mathrm{SD}(\mathrm{mg} / 100 \mathrm{~g} \mathrm{dw})$ at $95 \% \mathrm{CL}(\mathrm{n}=3)$} \\
\hline & & Cd & $\mathrm{Cr}$ & $\mathrm{Cu}$ & $\mathbf{P b}$ \\
\hline \multirow[t]{4}{*}{ S1 (Jangwani) } & Amaranthus blitum & $0.05 \pm 0.01^{\mathrm{beg}}$ & $29.08 \pm 0.14$ & $12.66 \pm 0.05$ & $4.36 \pm 0.01$ \\
\hline & Amaranthus gangeticus & $\bar{b} d l$ & $3.30+0.01$ & $7.68+0.02$ & $1.08+0.02^{\mathrm{fg}}$ \\
\hline & Ipomea batata & bdl & $0.14+0.01^{\mathrm{A} \mathrm{b}}$ & $1.14+0.01^{\mathrm{ce}}$ & $0.11+0.01^{\mathrm{A}}$ \\
\hline & Curcubita maxima & bdl & $10 . \overline{52}+0.03$ & $15.8 \overline{6}+0.02$ & $0.96+0.02^{\mathrm{f}}$ \\
\hline \multirow[t]{4}{*}{ S2 (Kigogo) } & Amaranthus blitum & $0.02 \pm 0.02^{\mathrm{cfg}}$ & $11.19 \pm 0.02$ & $6.75 \pm 0.17$ & $1.06 \pm 0.01^{\mathrm{g}}$ \\
\hline & Amaranthus gangeticus & $\overline{\mathrm{b}} \mathrm{dl}$ & $5.67 \pm 0.01$ & $4.72 \pm 0.01^{\mathrm{f}}$ & $0.48 \pm 0.01^{\mathrm{b}}$ \\
\hline & Ipomea batata & bdl & $0.14+0.01^{\mathrm{b}}$ & $0.97 \pm 0.02^{\text {be }}$ & $\overline{\mathrm{bd} l}$ \\
\hline & Curcubita maxima & bdl & $8.50 \pm 0.06$ & $13.3 \overline{8}+0.15$ & $0.65 \pm 0.01^{\mathrm{de}}$ \\
\hline \multirow[t]{4}{*}{ S3 (Tabata Shule) } & Amaranthus blitum & bdl & $1.73 \pm 0.01^{\mathrm{d}}$ & $11.98 \pm 0.03$ & $0.63 \pm 0.03^{\mathrm{de}}$ \\
\hline & Amaranthus gangeticus & bdl & $1.72 \pm 0.1^{\mathrm{d}}$ & $8.44 \pm 0.01$ & $0.60 \pm 0.01^{\mathrm{cd}}$ \\
\hline & Ipomea batata & bdl & $0.43+0.01^{\mathrm{c}}$ & $0.96 \pm 0.01^{\mathrm{de}}$ & $0.69 \pm 0.01^{\text {ce }}$ \\
\hline & Curcubita maxima & $0.01+0.01^{\mathrm{bcd}}$ & $7.19+0.06$ & $4.85+0.02$ & $0.80+0.01$ \\
\hline \multirow[t]{7}{*}{ S4 (Vingunguti) } & Amaranthus blitum & $0.01 \pm 0.01^{\mathrm{def}}$ & $2.53 \pm 0.02$ & $6.45 \pm 0.06^{1}$ & $1.49 \pm 0.17^{\mathrm{h}}$ \\
\hline & Amaranthus gangeticus & $0.5 \overline{3}+0.01$ & $4.54+0.15$ & $17.6 \overline{9}+0.13$ & $39.6 \overline{9}+0.17$ \\
\hline & Ipomea batata & $\overline{\mathrm{bd} l}$ & $0.42 \pm 0.01^{\mathrm{c}}$ & $0.76 \pm 0.01^{\mathrm{bcd}}$ & $1.51 \pm 0.01^{\mathrm{h}}$ \\
\hline & Curcubita maxima & bdl & $1.12+0.32$ & $6.1 \overline{6}+0.63$ & $0.40 \pm 0.01^{\mathrm{b}}$ \\
\hline & Permissible levels in food as per WHO \& FAO & 0.3 & 2.3 & 4.0 & 0.3 \\
\hline & Average concentration & 0.04 & 5.51 & 7.52 & 0.33 \\
\hline & Dietary intake (mg dw) & 0.042 & 5.79 & 7.90 & 0.35 \\
\hline
\end{tabular}

dw: dry weight, bdl: below detection limit, WHO: World Health Organization, FAO: Food and Agriculture Organisation, $\mathrm{p}<0.001,{ }^{\mathrm{A}}$ mean values in the same row are not significant different, $\mathrm{b}, \mathrm{c}, \mathrm{d}, \mathrm{e}, \mathrm{f}, \mathrm{g}$ mean values in the same column are not significant different. 


\section{DISCUSSION}

Peri-urban and urban rivers of developing countries often receive effluents from industrial or municipal wastewaters which are contaminated with heavy metals. Irrigation with water contaminated with heavy metals generally leads to soil pollution and consequently heavy metal uptake by vegetables (Muchuweti et al., 2006). Heavy metals determined in different vegetables showed that A. blitum and A. gangeticus accumulated maximum mean concentrations of the heavy metals $\mathrm{Cd}, \mathrm{Cr}, \mathrm{Cu}$ and $\mathrm{Pb}$ that are $0.53,29.17,17.69$ and $39.69 \mathrm{mg} / 100 \mathrm{~g}$, respectively (Table 2). The variations in the concentrations of heavy metals in vegetables may be ascribed to the physicochemical nature of the soil and absorption capacity of each metal by the plant, degree of maturity of the plants at the time of harvest and the nature of the plant (Voutsa et al., 1996). Consumption of contaminated vegetables may pose risk to human health. The mean concentrations of $\mathrm{Cr}$ and $\mathrm{Pb}$ in A. blitum, A. gangeticus and $C$. maxima exceeded FAO/WHO safe limits for human consumption (2.3 and $0.3 \mathrm{mg} / 100 \mathrm{~g}$ for $\mathrm{Cr}$ and $\mathrm{Pb}$, respectively). With exception to $A$. gangeticus collected from Vingunguti, the amounts of $\mathrm{Cd}$ in all other vegetables were within the permissible limits. The mean concentrations of heavy metals in I. batata were within the acceptable limits.

The mean concentrations of $\mathrm{Cu}$ and $\mathrm{Pb}$ were higher than those previously reported for vegetable in Msimbazi River by Bahemuka and Mubofu (1999). This indicates that cumulative effects as a consequence of increased anthropogenic activities and as a result of population increase accompanied with increased industrial activities such as paint, battery, textile, milling and chemical industries which introduce heavy metals into the river. The major sources of the heavy metals in the Msimbazi River were therefore envisaged to be industrial effluents, and indiscriminate disposal of untreated or partially treated domestic or sewage drainage directed to the river and its streams. Among the alarming sources include leachate from the solid waste dump at Kigogo and Vingunguti area (old dump), industrial effluents discharged from Tabata and Buguruni, Vingunguti abattoir and effluents from Vingunguti WSP's (waste stabilization ponds) which consists of various industrial, domestic, garage and agricultural wastes.

Heavy metals estimated daily intake through consumption of the four vegetables (Table 2), was found that with exception to $\mathrm{Cd}$, average consumption concentrations of $\mathrm{Cr}$ and $\mathrm{Cu}$ pose a health risk for the consumers as the values are above the FAO/WHO limits for heavy metals intake based on the body weight of an average adult (60 kg body weight). Provisional tolerable daily intakes (PTDIs) for $\mathrm{Cu}, \mathrm{Cd}$ and $\mathrm{Pb}$ are 3, 60 and $214 \mathrm{mg}$, respectively (Joint FAO/WHO, 1999). Previous estimates by Bahemuka and Mubofu (1999) were $21.6 \mu \mathrm{g}, 859 \mu \mathrm{g}, 427 \mu \mathrm{g}$ and 3.65 mg per day of $\mathrm{Cd}, \mathrm{Cu}, \mathrm{Pb}$ and $\mathrm{Zn}$, respectively. Estimates made from various countries have shown that the dietary intake for $\mathrm{Pb}$ in adults is between 54 and $412 \mathrm{mg}$ per day, $\mathrm{Cd} 10$ and $30 \mathrm{mg}$ per day, $\mathrm{Zn}$ and $\mathrm{Cu}$, the estimated daily intake is from 1 to $3 \mathrm{mg}$, and 10 to $20 \mathrm{mg}$, respectively (Bahemuka and Mubofu, 1999).

\section{Conclusion}

The present study has revealed heavy metal contamination in leaves of popular vegetables grown at four different sites that utilize water from Msimbazi River for irrigation. Most of vegetables sampled along Msimbazi River had maximum concentrations higher than WHO/FAO limits. Except for $\mathrm{Cd}$ and $\mathrm{Pb}$, the concentrations of other heavy metals were above limits allowed for human consumption, indicating a potential risk to every population sub group for carcinogenic and non carcinogenic effects through longterm dietary intake. The authors strongly recommend regular monitoring of these toxic heavy metals from industrial and anthropogenic effluents, Msimbazi River, in vegetables and other food materials in order to 
prevent their excessive build-up in the food chain.

\section{ACKNOWLEDGEMENTS}

We are gratefully acknowledging the inputs of Mr. Leonard Sibomana on this work, and Mr. Ado Ndimbo and Ramadhani Mbulume from the School of Environmental Science and Technology, Ardhi University for their invaluable technical assistance during the laboratory extraction and analysis.

\section{REFERENCES}

Ak'habuhaya J, Lodenius M. 1989. Metal Pollution of Msimbazi River Tanzania. Pergamon Press Plc, USA.

Bahemuka TE, Mubofu EB. 1999. Heavy metals in edible green vegetables grown along the sites of the Sinza and Msimbazi Rivers in Dar es Salaam, Tanzania. Food Chem., 66: 63-66.

Clesceri LS, Greenberg AE, Trussell RR. 1998. Standard Methods for Examination of Water and Wastewater $\left(17^{\text {th }}\right.$ edn). APHA-AWWA-WPCF Publishers.

Cui YJ, Zhu YG, Zhai RH, Chen DY, Huang YZ, Qiu Y, Liang JZ. 2004. Transfer of metals from soil to vegetables in an area near a smelter in Nanning. China. Environ. Int., 30: 785-791.

D'Mello JPF. 2003. Food Safety, Contaminants and Toxic. CABI Publishing: Cambridge.

Grasmück D, Scholz RW. 2005. Risk perception of heavy metal soil contamination by high-exposed and low-exposed inhabitants: the role of knowledge and emotional concerns. Risk Analysis, 25(3): 611-22.

Joint FAO/WHO Expert Committee on Food Additives. 1999. Summary and conclusions. In $53^{\text {rd }}$ Meeting, Rome, June 1-10.

Lukwanjo Z, Tanner M. 1985. Tanzania food and nutrition centre report no. 940/June.

Mashauri DA, Mayo A. 1990. The environmental impact of industrial and domestic waste water in Dar es Salaam. In Environmental pollution and its management in eastern Africa, Khan MR, Gijzen HJ (eds). Faculty of Science, University of Dar es Salaam: Dar es Salaam, Tanzania; 23-32.

Muchuweti A, Birkett JW, Chinyanga E. 2006. Heavy metal content of vegetables irrigated with mixtures of wastewater and sewage sludge in Zimbabwe: implications for human health. Agric. Ecosyst. Environ., 112(1): 41-48.

Mushtakova VM, Fomina VA, Rogovin VV. 2005. Toxic effect of heavy metals on human blood neutrophils. Biol. Bull., 32(3): 276-278.

Sharma RK, Agrawal M, Marshall FM. 2009. Heavy metals in vegetables collected from production and market sites of a tropical urban area of India. Food Chem. Toxicol., 47: 583-591.

Vousta D, Grimanis A, Samara C. 1996. Trace elements in vegetables grown in industrial areas in relation to soil and air particulate matter. Environ. Pollution, 94: 325-335. 